\title{
MAGMATISMO MESO-CENOZÓICO DA REGIÃO DA SERRA DA MANTIQUEIRA, SP/MG*
}

F.R.Alves

E.Ruberti

S.R.F.Vlach

O posicionamento geográfico e tectônico conferem importância destacada à investigação da Mantiqueira em seu registro magmático pós-paleozóico. Conhecimentos pessoais e da literatura levaram a programa de trabalho cobrindo $5.000 \mathrm{~km}^{2}$, em parte já cumprido. Detalhamento geológico de regiões conhecidas e de subáreas localizadas, registraram 60 novas ocorrências, com duas centenas de pontos de amostragem e cinco centenas de amostras coletadas. Atividade laboratorial prevista, já iniciada, inclue a petrografia, a química mineral e de rochas, bem como estudos isotópicos. Os primeiros resultados, de caráter preliminar, são apresentados. Tem-se, como meta, aclarar o quadro magmático (e tectônico) do Rift Paraíbano.

No registro magmático pós-paleozóico da área, é o maciço intrusivo, gabróide, de Ponte Nova o que mais se destaca; este porém não é o mais significativo: rochas de dique intermediárias, saturadas e insaturadas, alcalinas, como e, principalmente, as básicas e ultrabásicas (lamprófiros) constituindo enxames por toda a área entre Monteiro Lobato-Campos de Jordão-Piquete e o Vale do Paraíba.

O corpo de Ponte Nova parece dividido em dois: porção maior elíptica, com 3,5 por $2,5 \mathrm{~km}$, ao Norte, separa-se por $100 \mathrm{~m}$ de parte menor circular com diâmetro de $1 \mathrm{~km}$ ao Sul. Está encaixado em granitóides e rochas metamórficas de alto grau, truncando parcialmente as estrturas locais. Em poucos lugarares os contatos podem ser traçados com precisão e nunca foram observados diretamente. Rochas dos diques referidos e faixas cataclásticas cortam estas intrusivas. Megaxenólitos

*Projeto FAPESP 90/4848-0.

Departamento de Mineralogia e Petrologia, Instituto de Geociências, USP. 
graníticos são observados nas porções Centro-Sul. Petrograficamente, predominam os gabros, com texturas desde cumuláticas com granulações grossas e muito grossas, a rochas equigranulares de granulação média, ou ainda porfiríticas em matriz fina. As primeiras apresentam estruturas bandadas ("layering"), devidas a variações granulométricas (muito grossas a grossas) e composicionais (desde ultramáficas até hololeucocráticas). Localmente são observadas estruturas de escavação e estratificações cruzadas. As rochas de granulação mais grossa ocupam as partes mais baixas da morraria central e posições mais altas para Oeste; na medida que se sobe nos morros das porções centrais, passa-se para rochas cada vez mais finas, até porfirficas nas cristas $(1200 \mathrm{~m})$ e afaniticas pouco porfirfticas da borda oriental do maciço. Os tipos petrográficos dominantes são olivina-gabros e gabros que passam, por um lado, para leucogabros, monzogabros e plagioclasitos ("anortositos") e, por outro, para melagabros e olivina-clinopiroxenitos. Variedades sienfticas ocorrem raramente. A mineralogia é típica e monótona: a titanoaugita predomina entre os máficos, seguida por olivina magnesiana pouco alterada, ilmenomagnetita, kaersutita e biotita vermelha; plagioclásios intermediários a cálcicos são os félsicos essenciais. Menos comuns são, feldspato potássico, rara nefelina, apatita e espinélio, além dos minerais de alteração.

Diques de rochas intermediárias são encontrados cortando as rochas do maciço e nas vizinhanças até Santo Antônio do Pinhal (ao Leste) e Campos de Jordão (a Nordeste). Têm espessuras centimétricas/decimétricas a métricas com extenções não verificadas. As mesmas rochas também formam sapatas e associam-se a faixas cisalhadas e a brechas magmáticas. São, em geral, concordantes com a estruturação regional. Foram descritos traquitos saturados, fonolitos, estes portadores de aegirina, feldspatóides e zeólitas.

Os diques lamprofíricos, típicos alguns, duvidosos outros, são encontrados em grande quantidade e frequência em quase todos os locais examinados em maior detalhe. Cortam o Maciço de Ponte Nova e a partir dele ocorrem para E-NE até Campos de Jordão e Santo Antônio de Pinhal, e além, pelos contrafortes e sopés da Mantiqueira, até o Ribeirão Piaguí/Fazenda Lavrinha, N de Guaratinguetá. Constituem corpos isolados, com espessura centimétrica a métrica, ou corpos múltiplos, com até cinco deles justapostos. Em alguns locais, lamprófiros e fonolitos ocorrem lado a lado. Os diques apresentam zoneamento transversal, simétrico, com bordas afaníticas, seguidas de porção amigdaloidal ou ocelar e com centro porfirftico, com fenocristais idiomórficos. Poderiam ser chamados, no campo, de "olivina (piroxênio, anfibólio) lamprófiros" e, em parte, de "biotita lamprófiros". Dado as peculiaridades destas rochas, são classificados preliminarmente como lamprófiros alcalinos: monchiquitos, camptonitos e sannaitos. Incluem minerais como clinopiroxênios diversos, kaersutita \pm forsterita \pm biotita vermelha como fenocristais e, exceto a olivina, também matriciais; outros minerais 
são plagioclásio, feldspato alcalino, analcima, zeólitas e minerais não identificados e, minerais de alteração. Diversas amostras contêm, ainda, vidro intersticial.

Um único dique de diabásio orientado N-S, subvertical, foi encontrado na cabeceira do Ribeirão da Perutinga, ao Norte de Aparecida do Norte.

As informações apresentadas reúnem dados antigos reavaliados e novos resultantes de trabalhos iniciados em 1990. A par do estudo detalhado das amostras já coletadas, deve-se continuar o mapeamento em áreas selecionadas que progressivamente serão expandidas. É interessante observar a similaridade entre as rochas plutônicas que afloram no Maciço Ponte Nova $e$ estes diques com ocorrências melhor estudadas em outras regiöes tais como Klokken, na Groenlândia e as "Monteregian Hills", no Canadá. 